\title{
MetAP2 Inhibitor APL-1202
}

National Cancer Institute

\section{Source}

National Cancer Institute. MetAP2 Inhibitor APL-1202. NCI Thesaurus. Code C162480.

An orally available inhibitor of methionine aminopeptidase II type (MetAP2) with potential antiangiog enic and antineoplastic activities. Upon administration, APL-1202 binds to and reversibly inhibits MetAP2, thereby preventing MetAP2-mediated signal transduction pathways. This may suppress endothelial cell growth and inhibit tumor angiogenesis, resulting in tumor cell death. MetAP2, a member of the dimetallohydrolase family, is upregulated in certain tumor cell types and plays a key role in angiogenesis, proliferation and survival. 